\title{
Corporate Social Responsibility Intervention Of One Mining Operator: A Community Development Case In Bojanala District, South Africa
}

Prof J. Dubihlela, Cape Peninsula University of Technology, South Africa Antoinette B. Volschenk, African Mining and Trust Co. Ltd, South Africa

\begin{abstract}
The South African economy constantly experiences work stoppages, is gradually losing its pride and currently experiences decisive anomalous moments underpinning new operational perceptions. Mining organisations seem to be blamed for not doing enough social capital development initiatives, particularly in underdeveloped communities. This study examines in depth the role of a mining company's involvement in an identifiable community in South Africa's Bojanala District. Specifically, the study evaluates the steps followed in identifying needs and the usefulness of a mining-project designed to enhance capacity-building opportunities for young South Africans; a sustainable development initiative. Qualitative action research was used in this study to ensure a participatory approach of the data gathering processes to personal and professional transformation. Action research phases were followed in the manner of Maree (2014). The findings suggest that expectations for community development projects are greater in rural and peri-uburban South African communities. It was found that participants had a general inability to read, write, speak, listen and apply the mathematical proficiency that is needed in order to function effectively in an employment environment. The youth unemployment rate in the Bojanala District can be attributed to the gap between their level of education and the employment requirements. The miners are deemed to have a responsibility towards their communities and it is the youth of these same communities that look towards the mines for employment. Mining companies can contribute to education, skills development and training of the youth. If community engagement is taken seriously as a CSR strategic approach, this would enhance positive inter-relations between the mining companies and their communities.
\end{abstract}

Keywords: Corporate Social Responsibility; Sustainable Development Initiatives; Developing Countries; South African Youth; Mining Companies

\section{INTRODUCTION}

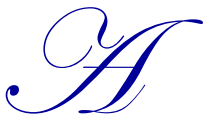

multitude of socio-economic challenges consistently affect communities in the Northwest Province of South Africa, particularly in the Bojanala District Municipality. These socio-economic challenges include extreme poverty (Sekhampu, 2013), poor health care and delivery (Lustig et al., 2014), extensive unemployment (Sekhatane, 2013), substandard education (DBE, 2013), lack of housing, increased violence against women and children and poor service delivery (Bhorat et al., 2014). Many of the socio-economic challenges mentioned can be attributed to the increasingly large number of unemployed people (Klasen \& Woolard, 2009) and the resulting poverty.

One of the factors contributing to the high unemployment levels is the poor educational level of our youth in South Africa (Bhorat et al., 2014). Furthermore, every year thousands more are added to the number of unemployed as matriculants continue to graduate from school with substandard qualifications (Lacour \& Tissington, 2011). Increased focus is placed on the percentage of passing matriculants as a measure of success of the country's education system (Brunello \& Checchi, 2007), yet little attention is paid to the standard of matric certificates the system delivers. 
The lack of resource-availability for our youths constantly affects the growing number of unemployed youths. In order to address this challenge more focus must placed on making resources available to the rural unemployed youths in the form of grants (Dubihlela \& Dubihlela, 2014), bursaries and other philanthropic projects (Schepers, 2014). However little attention is paid to the fact that even if the necessary resources were available, the level of education of the unemployed makes them unemployable or unable to pursue tertiary educational opportunities (Lacour \& Tissington, 2011).

In many instances individuals manage to source benefactors to assist with grants or bursaries only to be denied access to tertiary institutions due to their lack of entry level educational requirements (Engle \& Black, 2008). The question is whether this challenge could only be attributed to a poor level of education (Brunello \& Checchi, 2007) or could factors such as lacking career guidance in schools and subsequent gaps in levels of education and expectations be responsible. Even if we could identify only one single immediate culprit it would mean little to the masses of youth that are currently unemployed (Caliendo, Fossen, \& Kritikos, 2014). The focus therefore should not only be on what can be done to address the future challenges but serious attention needs to be focused on what needs to be done to address the current gap (Schepers, 2014) in order to change the status quo.

This study examines the levels of education within the above-mentioned communities surrounding the Rustenburg Mining Development Corporation (RMDC) and the community-engaged sustainability activities that the mining company is involved in. The aim of this research is to contribute towards building the sustainable human capacity development within the local communities to such an extent that it actually contributes to the alleviation of unemployment, highlighting other socio-economic problems and adding to the voices chanting forward as a 'community development and sustainability issue'.

\section{LITERATURE REVIEW}

The Rustenburg Mining Development Corporation (RMDC) is a mining company that is situated $73 \mathrm{~km}$ from Rustenburg and specialises in mining chrome deposits. RMDC operates in the Moses Kotane West region of the Bojanala District, with the following communities surrounding the mine: Makgophe, Molorwe, Witrandjies, Mabeskraal, Tweelaagte, Bapong, Moruleng, Seolong and Ramokokastad. According to Lehohla (2012) in the Census 2011 Municipal Report, the population in the North West is categorised according to age as follows: $26.4 \%$ are between the ages of 0 and 14, 68.3\% are between the ages of 15 and 64 and $5.3 \%$ are above 65 years of age. The total number of people in the Moses Kotane region is 242554 (Lehohla, 2012). The census report also indicates a population distribution of $91.7 \%$ black, $0.7 \%$ coloured, $0.6 \%$ Indian/Asian and $7.0 \%$ white (Lehohla, 2012). The Bojanala District has an unemployment rate of $30.7 \%$ and a $47.3 \%$ dependency ratio, which means that $4 \%$ of the population is dependent on government grants in order to survive.

The education levels indicate that $7.6 \%$ of the population have no schooling, $28.6 \%$ have a matriculation qualification and a mere 7.4\% have a higher education qualification (Brunello \& Checchi, 2007; Lehohla, 2012). It is evident from the census report that the Bojanala District is an area with high unemployment and a high dependency ratio, in addition to very low education levels. Altbeker et al. (2014:12) have drawn up a list of 20 youth unemployment hotspots in South Africa. The RMDC falls within the Rustenburg/Madibeng municipalities mentioned in the following table as being among the top twenty (Table 1). 
Table 1. The Top Twenty Youth Development Hotspots in South Africa

\begin{tabular}{l|c|c|c|c}
\hline \multicolumn{1}{c}{ Municipality } & $\begin{array}{c}\text { Youth unemployment } \\
\text { rate \% }\end{array}$ & $\begin{array}{c}\text { Number of } \\
\text { unemployed youth }\end{array}$ & $\begin{array}{c}\text { Number of } \\
\text { discouraged youth } \\
\text { work seekers }\end{array}$ & $\begin{array}{c}\text { Unemployed and } \\
\text { discouraged young } \\
\text { work seekers }\end{array}$ \\
\hline Johannesburg city & 31.5 & 387000 & 70000 & 457000 \\
\hline eThekwini (Durban) & 39.0 & 309000 & 80000 & 389000 \\
\hline Ekurhuleni Municipality & 36.9 & 310000 & 54000 & 364000 \\
\hline City of Cape Town & 31.9 & 277000 & 55000 & 332000 \\
\hline City of Tswane & 32.6 & 237000 & 42000 & 131000 \\
\hline Nelson Mandela Bay & 47.3 & 105000 & 26000 & 88000 \\
\hline Emfuleni Municipality & 45.0 & 75000 & 13000 & 79000 \\
\hline Buffalo City & 45.1 & 61000 & 18000 & 70000 \\
\hline Msunduzi & 43.1 & 53000 & 17000 & 68000 \\
\hline Mangaung & 37.2 & 56000 & 12000 & 67000 \\
\hline Bushbuckridge & 64.6 & 46000 & 15000 & 61000 \\
\hline Mbombela & 37.6 & 46000 & 9000 & 59000 \\
\hline Polokwane & 42.0 & 50000 & 21000 & 59000 \\
\hline Thulamela & 58.3 & 38000 & 8000 & 57000 \\
\hline Rustenburg & 34.7 & 49000 & 8000 & 52000 \\
\hline Madibeng & 38.2 & 44000 & 9000 & 48000 \\
\hline Matjhabeng & 49.7 & 39000 & 15000 & 45000 \\
\hline Makhado & 49.6 & 30000 & 6000 & 42000 \\
\hline Emalahleni & 36.0 & 36000 & 7000 & 42000 \\
\hline Greater Tubatse & 59.6 & 35000 & & \\
\hline Source: & & & & \\
\hline
\end{tabular}

Source: Altbeker et al. 2014:12

Owing to the cyclical nature of the chrome industry, the profit margin is not stable and it has an effect on the chrome mine's community's economic development budget (Lazenby, 2014). Thus it is essential for such mining companies that all community development projects produce maximum return on investment, not only by satisfying legislative requirements but also in terms of actual development of the community (Martinez, 2013).

Recent incidents of rioting and arson at the RMDC instigated by the youths resulted in consultation between the community tribal councils and the management of the RMDC. The consultation process indicated that unemployment, and a lack of training and skills development were the core instigative factors of the incidents that occurred (Schepers, 2014). Currently, the RMDC follows a skills development and training model compiled by the skills development and training manager, with fair results among employees. However, even though the RMDC has focused on assisting the community's schools and employees, it has failed to extend the model to the community youth not employed by the mine.

Capacity building is growing in importance because the main contributor to slow economic growth in developing countries is the quality of human capacity (Schepers, 2014). Todres et al. (2006:61) explain that capacity building does not include only one discipline but incorporates empowerment, community development, education and health. They add that capacity building assists in self-sustainability as the community's ability to recognise, analyse and solve its challenges increases to such an extent that it can control the internal and external resources far more effectively (Todres et al., 2006:64). Capacity building as a component of development is becoming increasingly important in intervention programmes as it is critical in achieving the goals of community development (Wataya, 2011:183). McAllister, Street and Wyatt (2015) maintain that capacity building is critical to sustainable development as the strengthened capacity remains long after the intervention programme has ended or the funds have been depleted. Nafukho (2013:605) says that the main goal of development is improving the standard of living in communities and that capacity is the knowledge, ability, critical thinking and learning necessary for development to take place.

The reason for the slow development in developing countries can be attributed to the lack of economic growth. Nafukho (2013:608) points out that economic growth is related to input quality; therefore, investing in human capacity through education and training is important. In fact, Nafukho (2013:608) argues that without investing in intellectual 
capital Africa will not be able to grow and will remain a disadvantaged continent. Ahmed and Hanson (2011:102) confirm this statement, observing that the economy of Africa is in such a fragile state because of the large knowledge gaps that exist. Intellectual means are necessary to ensure that our natural and physical resources are utilised effectively and efficiently (Nafukho, 2013:608). Nafukho (2013:809) explains that resourcefulness, through application of skills and knowledge, is what currently determines wealth in the world economy. Al-Roubaie (2010:118) points out that $50 \%$ of services and goods produced in industrial countries are knowlegde-based products. If Africa has any hope of catching up with industrial countries it needs to focus on developing capabilities (Al-Roubaie, 2010:114).

\section{STATEMENT OF THE PROBLEM}

Although many changes have taken place in South Africa, the development of the rural regions remains a big challenge and not enough has been done to alleviate the poverty in these regions (Chen \& Hsu, 2014:2). Research on the subject of corporate social investment, mining operators' social responsibility and their youth development initiatives, particularly in poor communities is South Africa, is minimum. The World Bank, cited in Al-Roubaie (2010:114), recommends that Africa should stop focusing merely on transforming its resources to financial resources but should rather transform its resources into items that can generate a higher return on investment. Innovation of this kind requires a high level of knowledge, creativity and development (Al-Roubaie, 2010:115). Learning new skills and techniques also leads to a higher level of productivity and, ultimately, to cost reductions (Al-Roubaie, 2010:117). Because developing countries compete with industrialised countries in the economy, it is important to enable people to deliver innovative products and methods of production (Al-Roubaie, 2010:118).

Ahmed and Hanson (2011:106) observe that, because of the large growth in the youth population, there is a greater percentage of people in Africa in the 25-year age group than in the under-50 year age group. Capacity-building programmes should therefore focus on youth development (Ahmed \& Hanson, 2011:106). Furthermore, poverty in many families forces children to leave school in order to assist in providing for the family and, for the majority of those children that manage to finish school, tertiary education remains but a dream (Sayed \& Badat, 2014:127).

Capacity building projects should actually become increasingly popular with mines as it is not merely the community that benefits from these projects but all stakeholders benefit (Chen \& Hsu, 2014:15). In focusing capacity building particularly on the youth, a new generation is formed that could take charge of their own lives, could become responsible adults and could play a vital role in national development (Lemmen, 2013). Furthermore, the challenge of unskilled rural youth migrating to the urban areas strengthens the cycle of rural impoverishment and exacerbates urban bias. The National Youth Publication thus stresses the urgency of investment in rural areas in terms of youth development (Lemmen, 2013). The aim of the study was to establish how the RMDC could contribute towards the development of the capacity of the unemployed youth (McAllister et al., (2015) in order for them to achieve their personal expectations and become employable.

\section{RESEARCH METHODOLOGY}

Numbers and statistics could go only so far in realising the goal of this study and therefore the researcher decided to follow a more personal and flexible research design (De Vos et al., 2010:268). Action research is the chosen qualitative research method because of the participative approach that contributes to personal and professional transformation (McNiff, 2013:52). Action research phases proposed by Maree (2014:127) are used as a guideline to follow during this research study. Phase 1: practical challenge phase, phase 2: reflection phase, phase 3: research phase, phase 4: planning phase and phase 5: action phase. A research protocol was established by the researcher and planned according to the action research phases. The protocol was designed in an effort to cut down on time and resources.

The protocol prescribed that during the practical challenge phase a youth focus group was to be established to represent the youth in discussions. The reflection phase included discussions with the other stakeholders such as the tribal authorities and representatives from the RMDC. The research phase consisted of data collection, analysis and coding to establish the gaps and investigate options available. In the planning phase a strategy was developed and feedback given to all the stakeholders. The final action phase would realise the strategy that was agreed on during phase 4 . 


\section{Sampling}

The research population is made up of individuals between the ages of 18 and 35 years, deemed as youth according to the South African norm. All the participants needed to reside in the communities in the Moses Kotane West area of the Bojanala district.

The researcher needed information regarding a specific topic within a specific group. In this research study the key variables were the educational levels of the unemployed youth population of two communities within Bojanala, namely Makgophe and Malorwe, the job expectations and the gap between the levels of education and expectation. The management of the RMDC identified the two communities as they are situated closest to the mine and are thus most affected by their mining operations.

Qualitative research requires no set standard in terms of sample size but suggests that the purpose of the study normally guides the researcher. The sample size for this research study is 67 young people, the majority of whom are postmatriculants, both male and female and all of whom are black Africans.

\section{Research Design}

The research instruments utilised during this qualitative research were focused questionnaires that were deemed suitable for focus groups and one-to-one in-depth interviews.

\section{Group Forums}

The researcher established focus groups to represent the different stakeholders in the study which enabled a trust relationship between the researcher and the various stakeholders (Caliendo et al., 2014). These discussions also gave the researcher the opportunity to document the information gathered during the sessions formally in minutes or notes (Saunders, 2006). The researcher was granted the opportunity to view the issues from the different perspectives of each group and to have a better understanding of the challenges that each of the groups face.

\section{In-Depth Interviews}

Due to the sensitivity and personal nature of the information required from the individuals, one-on-one interviews were held with all the participants (Sweeney, Bazemore, Phillips, Etz \& Stange, 2012). The interviews were conducted by four interviewers in order to cut down on time. Semi-structured interviews rather than unstructured interviews were more appropriate for the purpose of this study as the interview needed to be structured around a specific topic while still maintaining flexibility in depth or scope (De Vos et al., 2010:292). The fact that more than one interviewer was used also made semi-structured interviews more appropriate, ensuring that the interviewers asked the same questions and collected comparable data. During the unstructured part of the interview the participants needed to share their expectations regarding finding a job, their future skills development and training requirements in line with Sweeney et al. (2012). This part of the interview could not be structured as each participant had different requirements based on their individual choices and skills levels.

\section{Fieldwork}

A time schedule was drawn up for the interviews but the researcher soon realised that this time schedule was not going to go according to schedule as the participants arrived at random times. The researcher then decided to proceed with interviewing the participants on arrival, which would cut down considerably on waiting time. The interview consisted of guided questions as the aim of the interview was to obtain comparable and comprehensive data on a specific topic (De Vos et al., 2010:292). A questionnaire consisting of a set of predetermined questions and an interview schedule were compiled to guide the interviewer. This instrument ensured the interviewers were prepared in terms of wording, appropriate content and sensitive areas. 
Past unrest situations led the researcher to anticipate challenges with trust, antagonistic attitudes and the possibility of a hostile environment. In order to address the challenges, the researcher planned as many information sessions and introductory sessions as possible to ensure that the participants were familiar with the stakeholders and their background. Furthermore, the researcher focused on promoting transparency and on being friendly, respectful and approachable. Establishing rapport and trust with the participants was the only way to ensure the cooperation of the youth.

\section{DATA ANALYSIS}

In line with De Vos et al. (2010:333), the data analysis of a qualitative nature transforms the information into findings. Qualitative data analysis also reduces the volume of raw data, sifts the significant information from trivial inferences, identifies patterns of significance and communicates the results through a constructed framework (Sweeney et al. 2012).

\section{Preliminary Analysis}

Because the participants were not comfortable with the interviews being recorded, notes were taken. De Vos et al. (2010:336) point out that data collection and analyses in qualitative research do not always occur separately and that analytical insights occurring on site are also valuable. For instance, deducing that the antagonistic attitude with regard to the recordings could be an indication of the level of distrust and the poor relationship the community has with the RMDC, this research study focused on overlapping data collection and analysis in order to increase the quality of data and of analysis.

\section{Organising of Data}

The collected data of this research study were organised into electronic form by being typed and categorised on an excel spreadsheet. Once data were captured on the spreadsheet, the researcher further categorised the data into tables of interests. The participants were awarded a participant number during data collection. The participant number started with either MAL or MAK before the numbers to indicate whether the participant originated from Malorwe (MAL) or Makgophe (MAK). The participants were included on the spreadsheet according to the random sequence in which they were interviewed.

\section{Coding Of Data}

Categorising is the process of grouping themes or concepts that belong to a similar phenomenon (De Vos et al., 2010:340). The captured data were initially categorised on a spreadsheet according to the questions asked. Then the information was categorised according to the levels of education in South Africa: NQF level 1 to 8, in a table. A further categorisation was done according to the industry, the discipline and the training required by the participants.

\section{Measurement Validation}

Validity refers to whether the findings in the research study accurately reflect the situation in the communities surrounding the RMDC and whether the findings can be supported by evidence (De Vos et al., 2010:346). A method that the qualitative researcher could use to establish is data triangulation, which involves the use of a variety of sources of information (Guion et al., 2011:1). The sources could include participants, other researchers, programme staff and other stakeholders in the study (Sweeney et al., 2012). In this research study the sources of information were the participants' interviews, documentation, comments of tribal authority members and input from training providers. All the participants were required to produce their school or tertiary education certificates during the interview session.

Theory triangulation was used to establish the validity of the information by asking the input of a professional within the training discipline to verify information (Hussein, 2009:1). Investigator triangulation confirms validity when more than one researcher is used during any stage of the research study (Hussein, 2009:3). During the analysis stage in this study, the documents and notes from the interviews were reviewed by the researcher and training providers in order 
to ensure that the findings were credible (Guion et al., 2011:1). Reliability in this study was not a concern as the answers to the questions in the interview would remain stable if the questions were repeated. The participants' educational level would remain the same during the time of the research study. However, if the study were to be repeated in the future the answers might change as the circumstances of the participants might have changed. Therefore time would affect the reliability of the study.

Reliability with regard to the participants' answers as to what they would like to study and achieve may be questionable as they might change their minds after the career guidance session. The participants may have had an idea of what they would like to study but upon assessing the requirements they could come to the conclusion that their academic skills were not suitable for that particular field. Therefore time was not the only factor that could affect reliability; additional information could play a role as well.

\section{RESULTS AND DISCUSSION}

During the first and second phases the social issue was identified, reflected on and discussed by the stakeholders. In the first phase the researcher established a youth committee which included a tribal council representative, four Malorwe youths and four Makgophe youths. During discussions with the youth committee it became evident that the young people were upset mainly by their state of unemployment. They felt that it was the responsibility of the mines in the area to establish jobs and develop the communities.

The second phase of the study discussions with the Makgophe Tribal Authority confirmed that three main areas needed to be focused on employment, the building of a sports facility and training. A list of issues was identified during the discussions with the Makgophe Tribal Council and possible opportunities for intervention were identified to propose to the management of the RMDC. The third research phase involved the collection in the form of submission of CVs and one-to-one interview sessions to gather the information required in establishing the educational level of the 67 participants. The one-to-one interview sessions indicated the following levels of education found in the sample group:

- 1 participant on NQF Level 5 (Tertiary level)

- 35 participants on NQF Level 4 (Equivalent to grade 12)

- 3 participants on NQF Level 3 (Below grade 12)

- 9 participants on NQF Level 2

- 10 participants on NQF Level 1 and below (ABET level) 
Table 2. Levels of education in South Africa

\begin{tabular}{|c|c|c|c|c|}
\hline \multicolumn{4}{|c|}{ Levels of Education in South Africa } & \multirow{2}{*}{$\begin{array}{l}\text { Research } \\
\text { Current }\end{array}$} \\
\hline $\begin{array}{l}\text { Education } \\
\text { Catergory }\end{array}$ & $\begin{array}{l}\text { School } \\
\text { Grade }\end{array}$ & NQF Level & Qualifications & \\
\hline \multirow{10}{*}{ Higher } & & 8 & Doctor's degree & - \\
\hline & & \multirow{3}{*}{7} & Master's degree & - \\
\hline & & & Honours degree & - \\
\hline & & & Postgraduate diploma & - \\
\hline & & \multirow{3}{*}{6} & General first degree & - \\
\hline & & & Professional first degree, postgraduate & - \\
\hline & & & Bachelor's degree & - \\
\hline & & \multirow{3}{*}{5} & First diploma & 1 \\
\hline & & & Higher certificate & - \\
\hline & & & Certificate & - \\
\hline \multirow{3}{*}{ Further } & 12 & 4 & Diploma & 35 \\
\hline & 11 & 3 & Certificate & 11 \\
\hline & 10 & 2 & Certificate & 9 \\
\hline \multirow{10}{*}{ General } & 9 & 1 & Grade 9 & 10 \\
\hline & 8 & & Adult Basic Education and Training Level 4 & ABET $4=6$ \\
\hline & 7 & & & ABET $3=3$ \\
\hline & 6 & & & ABET $2=1$ \\
\hline & 5 & & & \\
\hline & 4 & & & \\
\hline & 3 & & & \\
\hline & 2 & & & \\
\hline & 1 & & & \\
\hline & $\mathrm{R}$ & & & \\
\hline
\end{tabular}

Source: Department of Basic education (2013)

The data indicated that only $1 \%$ of the 67 participants were at a level of education above grade 12 (Table 2). The participants who could present a grade 12 certificate or an equivalent NQF 4 certificate comprised $53 \%$ of the sample group. The percentage of participants with NQF level 1-3 was $32 \%$, which means that $32 \%$ of the participant group did not have the minimum requirement for most tertiary education training courses. Furthermore, an alarming $14 \%$ of the group were on ABET level, which means they had challenges with reading, writing and basic mathematical skills. 
Figure 1. Makgophe and Malorwe youth educational level

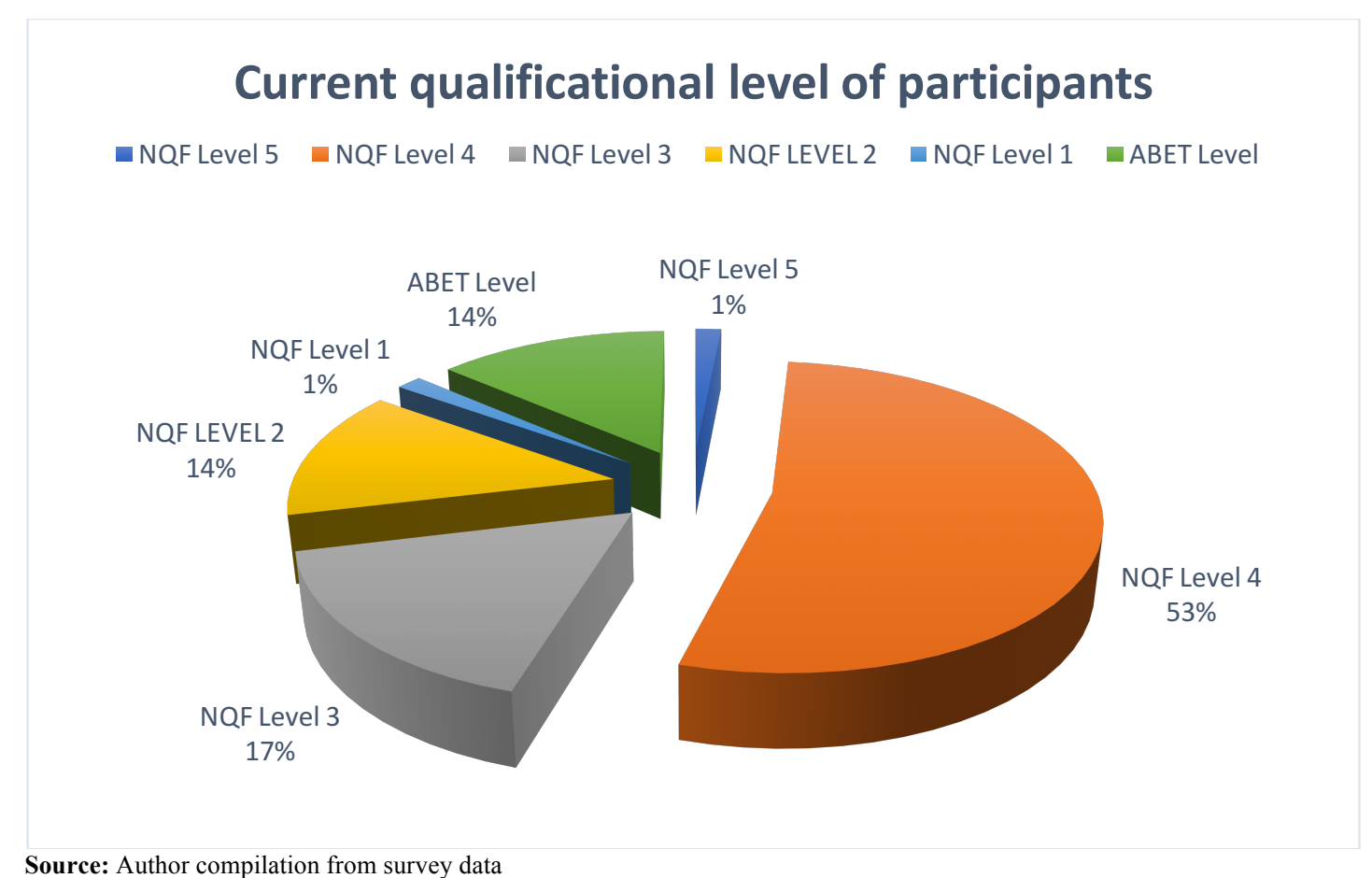

Source: Author compilation from survey data

During the interviews the participants were asked to indicate the kind of jobs that they would like to have and this information was mapped in the "wish list" table. The main aim of the wish list was to determine what the desired needs were in comparison with the current reality.

The information in the table was mapped under the headings of industry, discipline, training required, number of participants and the number of participants that possess the entry-level requirements for the training they require (Table 3). The research indicated a variety of training and skills development needs, with a majority of the requests focused on jobs in the mining industry. However, there were cases in which the training the individuals requested and the entry requirements did not match the individuals' skills levels. 
Table 3. Skills development needs in Makgophe and Malorwe

\begin{tabular}{|c|c|c|c|c|}
\hline Industry & Discipline & Training & No. & Qualified \\
\hline \multirow{15}{*}{ Mining } & \multirow{3}{*}{ Mining } & Rock Drill Operator & 3 & 2 \\
\hline & & Winch Operator & 3 & 3 \\
\hline & & Blasting ticket & 2 & 1 \\
\hline & Process & Process operator & 1 & 1 \\
\hline & \multirow{3}{*}{ Mining support } & Safety officer & 5 & 3 \\
\hline & & Quality inspector & 2 & 1 \\
\hline & & Survey & 2 & 0 \\
\hline & \multirow{5}{*}{ Engineering } & Boilermaker & 3 & 0 \\
\hline & & Electrical engineering & 4 & 0 \\
\hline & & Engineering & 3 & 1 \\
\hline & & Mechanical engineering & 3 & 2 \\
\hline & & Rigger / Rigger Aide & 1 & 0 \\
\hline & \multirow{2}{*}{ Maintenance } & Plumbing & 4 & 2 \\
\hline & & Carpentry & 3 & 2 \\
\hline & Support & Human Resources & 2 & 2 \\
\hline \multicolumn{3}{|l|}{ Subtotal } & 41 & 18 \\
\hline \multirow{5}{*}{ Local Government / Community } & \multirow{2}{*}{ Health } & Auxiliary Nursing & 9 & 1 \\
\hline & & Paramedic & 1 & 0 \\
\hline & Social Work & Social Work & 1 & 1 \\
\hline & Police & Police Officer & 1 & 1 \\
\hline & Education & Teaching & 6 & 2 \\
\hline \multicolumn{3}{|l|}{ Subtotal } & 18 & 5 \\
\hline \multirow{3}{*}{$\begin{array}{l}\text { Hospitality/ Tourism/ } \\
\text { Entertainment }\end{array}$} & & Chef & 1 & 1 \\
\hline & & Film making & 1 & 0 \\
\hline & & Tourism & 1 & 0 \\
\hline \multicolumn{3}{|l|}{ Subtotal } & 3 & 1 \\
\hline \multirow[t]{2}{*}{ Other } & Business & Business Training & 3 & 3 \\
\hline & Matric & Complete Grade 12 & 2 & 1 \\
\hline \multicolumn{3}{|l|}{ Subtotal } & 5 & 4 \\
\hline \multicolumn{3}{|l|}{ Total respondent group } & 67 & 28 \\
\hline
\end{tabular}

Source: Author compilation from survey data

Figure 2 report the information indicating that $58 \%$ of the group had unrealistic expectations in terms of their entry requirements into their desired training requests. This challenge indicated the need for career guidance among this specific group, among the youth in general and at school level in particular. The assessment of the certificates indicated that the majority of participants needed training in Grade 12 mathematics and in communication in order to reach their desired training or employment level. 
Figure 2. Participants qualification and training needs

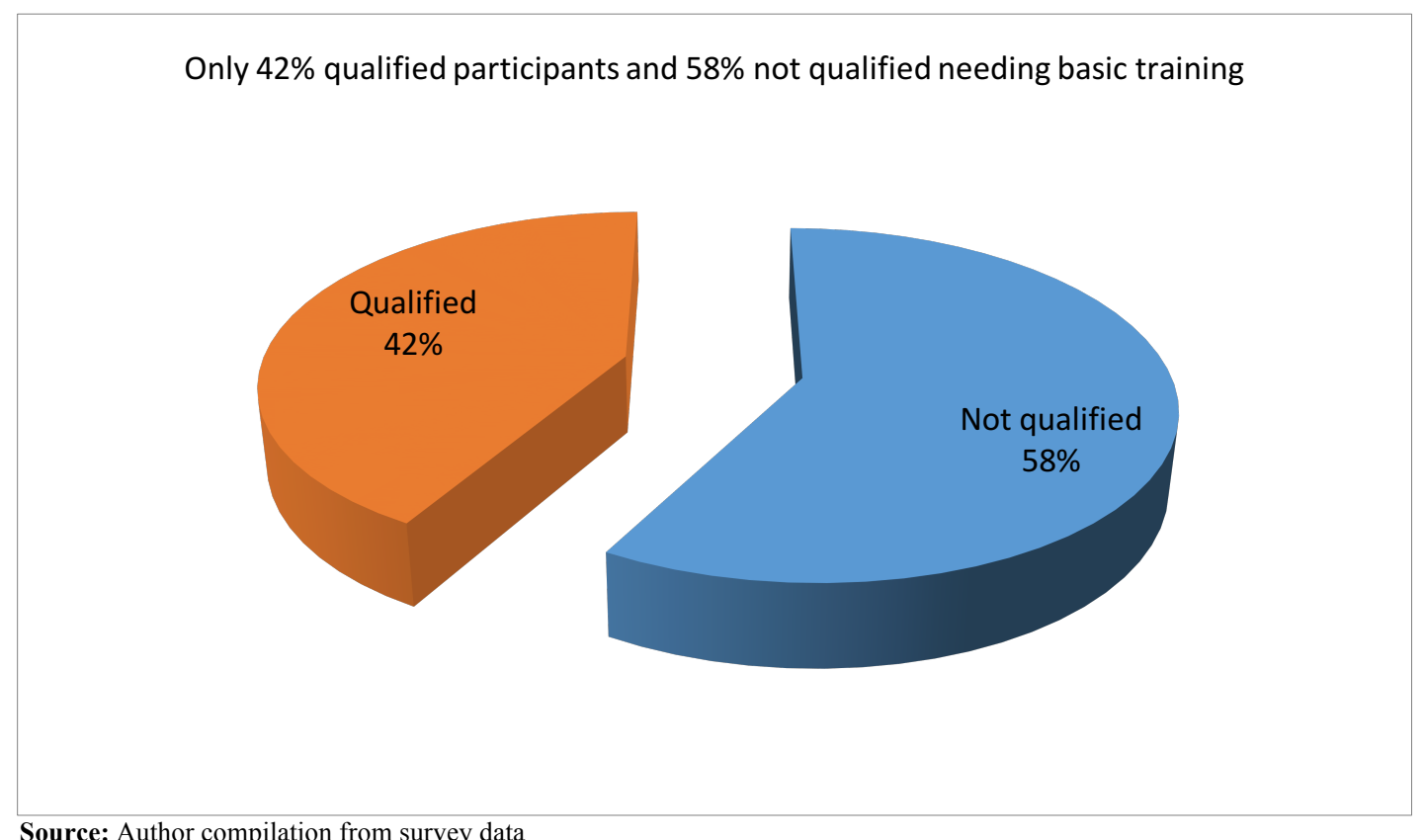

Source: Author compilation from survey data

Figure 3 reports that the current skills capacity of the community youth ranges from below NQF Level 1 to NQF Level 4. According to the desired needs analysis, the skills capacity of the community needed to shift from below NQF Level 1 to NQF Level 2 and from NQF Level 4 to NQF Level 6 (see Figure 3). The social issues identified by the youth and the tribal authority were employment, skills development or training, and a recreation facility.

Figure 3. Skills gap 'capacity versus status quo'

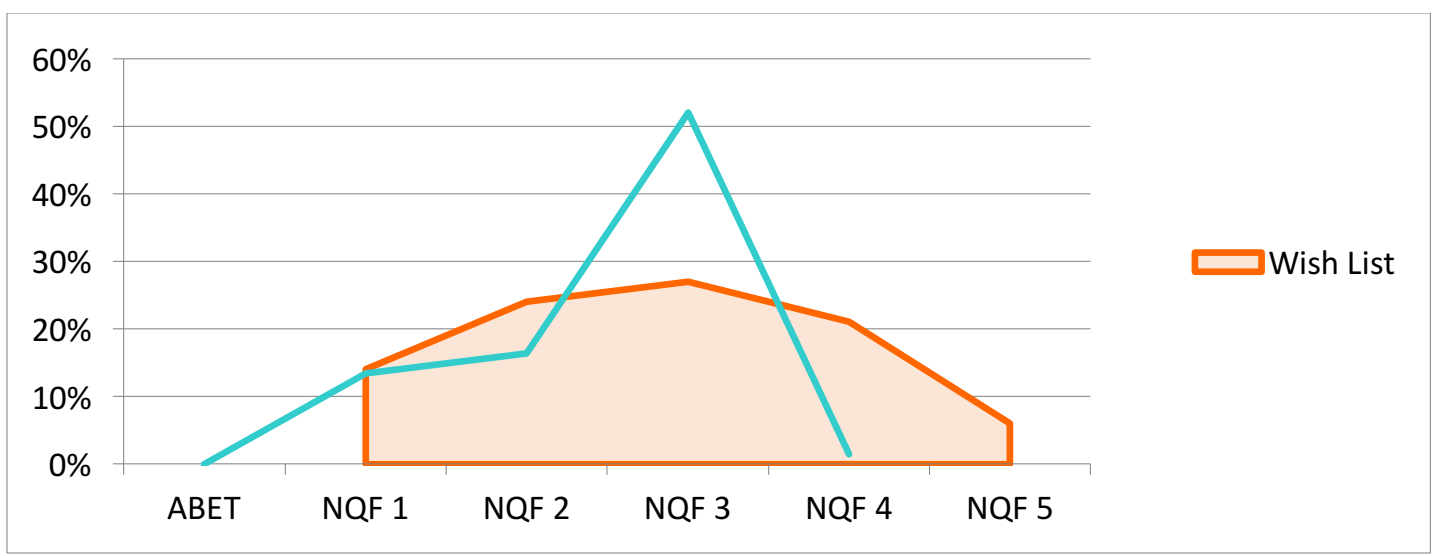

Source: Author compilation from survey data

Even though employment and skills development and training were identified as two separate issues, the study indicated that the two issues were closely related. It was clear that the participants were unemployed because of their lack of training and skills. The majority of the participants did not have the basic requirements to cope with occupational learning demands or to be employed at entry level. The findings indicated a desperate need for mathematics and communications skills. The unrealistic expectations of the participants with regard to future 
employment and training implied a skills gap. The unrealistic expectations also suggested a serious need for career guidance as the majority of the participants were ignorant of the basic educational requirements for their "wish list" career or further training.

The first objective of this research study was to identify the educational levels of the unemployed youth in the communities surrounding the RMDC. Because of time and budget constraints, the RMDC limited the study to the Makgophe and Malorwe communities. During the first phase of the study the social issues were confirmed as being employment, training and a required recreational facility. The study focused mostly on the training issue, as skills acquisition may partially address the unemployment issue.

It was found that $54 \%$ of the participants had a Grade 12, an equivalent NQF Level 4 or higher qualification. The remaining $46 \%$ of the participants did not have a Grade 12 or equivalent qualification. The percentage of participants with a NQF Level 3 qualification was $16 \%$, while $3 \%$ of the participants had a NQF Level 2 qualification. This means that 11 of the 67 participants had passed Grade 11 and a further 9 had passed Grade 10 and then left school. The most concerning finding was that $14 \%$ of the participants were on ABET Levels, which meant that 9 of the 67 participants could neither not read or write. Once these findings were established, the researcher could proceed to determine the gaps in terms of skills required for entry-level employment or further training.

In order to establish the skills gap it was necessary for the researcher to get an indication of what the participants aspired to. During the interview the participants were asked what type of employment they wished to obtain or what training they wished to embark on. The findings indicated a misconception of what the participants expected they could achieve with their current educational levels. The information indicated that $58 \%$ of the participants did not have realistic expectations with regard to the training they could receive. These participants either did not have the grade levels or the level of mathematical or communication skills for entry into the training courses they wished to pursue. The data indicated that a shift was needed in skills capacity from a Pre-NQF Level 1 to NQF Level 2 and from NQF Level 4 to NQF Level 6. This was the skills gap that the RMDC needed to address in order to ensure the participants met entry-level employment and training requirements.

Furthermore, these findings indicated that there was a dire need for career guidance as the majority of the participants had unrealistic expectations of what they could achieve with their current level of education. The findings indicated a gap in terms of progressing to occupational NQF Level 3 and 4 qualifications. In general it was found that the participants had a general inability to read, write, speak, listen and apply the mathematical proficiency that is needed in order to function effectively in an employment environment (DBE, 2013). Progression to a NQF Level 4 qualification often makes the difference between being unemployed or employed. If this is taken into consideration, the gap in terms of progression could be filled by the Foundational Learning Competence (FLC) part qualification. The findings indicated that 20 of the youths in the study required FLC training. The FLC training focuses on unemployed workers and aims to provide a work-related part qualification, which means that the learners will be more employable as this course increases their trainability and supports a business-related culture.

The following strategy was recommended and includes career guidance, Foundational Learning Competence (FLC) training and employment suggestions. The unrealistic expectations of the entry requirements for the desired training requests of the participants raise the question of whether the participants need career guidance. The researcher therefore proposes a career guidance workshop for the 67 young people in the sample group. The researcher assumes that a poor general career knowledge level could be generalised to the entire Moses Kotane Local Municipality West area. Because the majority of the participants need mathematics and communication skills to cope with occupational learning demands, a foundational learning training course is proposed. This would lead to at least an appropriate level of communication and mathematical literacy, thus allowing the youth entry into NQF levels 3 to 4 occupational qualifications.

\section{CONCLUDING REMARKS}

The findings indicate an enormous challenge with regard to young people graduating from high school with qualifications that are neither suitable for employment nor suited further education. This gap indicates that research is 
necessary in terms of the education, training and skills development needs of the youths in South Africa, and how high school qualifications need to be aligned with further education and the job market (Engle \& Black, 2008).

From the findings, it was confirmed that the majority of the young people were interested in employment within the mining industry, particularly those close to their communites. Should this be the case in most communities surrounding the mines in South Africa, it might be beneficial for the students if mining-related subjects were offered at these schools. This would mean that students leaving school could be ready to be employed at entry level within the mines. The researcher suggests research within the schools surrounding the mines to establish whether most of the students intended applying for mining-related positions after school. Should this be the case, further research could investigate the skills required by the mines for entry-level employment and recommendations could be made to the Department of Education to offer subjects that include the development of such skills at high school level.

The findings also indicated that the youths had a lack of proficiency in mathematics and poor communications skills. Research in terms of the mathematics and English subjects in the schools is thus imperative. Research could question the content of the subjects, the teachers' proficiency, the curriculum, the teaching methods, the subject material and resources available to the students.

Another gap that was evident from the findings was the gap between what the youths thought they could achieve with their skills levels and the reality. The youths expected to be employed or to receive further training yet their skills levels were below the standard required by employers or further training institutions. The researcher thus suggests future research into career guidance in rural schools in South Africa as the lack of knowledge found with regard to the requirements for post-matric training is a matter of concern.

Owing to the responsibility that the mines in South Africa have towards the communities surrounding their operations, it might be beneficial to direct some of their community development budget toward research in the schools surrounding their mines. The mines have a responsibility to the development of their communities and it will be the youth of these same communities that will look to the mines for employment soon enough. Contributing to the education of the youth in order that they can be more easily absorbed into the employment sphere might contribute to better relationships between the mines and their communities.

\section{IMPLICATIONS AND LIMITATIONS}

Although this study makes considerable contributions to research knowledge and practice, but due to a lack of resources and limited time, the research study focused only on two communities within the labour-sending area surrounding the RMDC. In order to establish whether the findings are indicative of all the communities surrounding the RMDC, a research study on a larger scale would have to be undertaken; conceivably the availability of resources would have enabled data to be gathered from across the country. Also, different research methodologies would yield variant results and add value to the subject of sustainable development.

\section{ACKNOWLEDGEMENTS}

The researchers would like to appreciate the anonymous referees for some highly useful comments on the earlier versions of this paper. Authors are also grateful to the Nelson Mandela Metropolitan University for providing seedfunding for the publication of this study.

\section{AUTHOR INFORMATION}

Job Dubihlela (PhD) is currently an Associate Professor in the Faculty of Management and Economic Sciences at the Cape Peninsula University of Technology, South Africa. He is a seasoned banker turned academic. He has published various papers in peer-reviewed international and national journals. He is currently involved in research programs on the social enterprises audits, environmental and sustainability issues in South Africa. E-mail: dubihlelaj@cput.ac.za (corresponding author) 
Antoinette B. Volschenk is manager within the Community Economic Development Department of the African Mining and Trust Co. Ltd., Illovo, Gauteng, 2196, South Africa.

\section{REFERENCES}

Ahmed, A. \& Hanson, K. (2011). Leadership, capacity building and sustainable development in contemporary Africa. World Journal of Entrepreneurship, Management and Sustainable Development, 7(4): 101-11.

Al-Roubaie, A. (2010). Building indigenous knowledge for development. World Journal of Science, Technology and Sustainable Development, 7(2): 113-29.

Altbeker, A., Storme, E. \& Bernstein, A. (2014). Young people and opportunity in South Africa's cities. Centre for Development and Enterprise Round Table, 24: 1-33.

Bhorat, H., Cassim, A., \& Tseng, D. (2014). Higher education, employment and economic growth: Exploring the interactions. DPRU-LMIP Report II. Cape Town: Development Policy Research Unit, University of Cape Town.

Brunello, G., \& Checchi, D. (2007). Does school tracking affect equality of opportunity? New international evidence. Economic Policy, 22(52): 782-861.

Caliendo, M., Fossen, F., \& Kritikos, A. S. (2014). Personality characteristics and the decisions to become and stay selfemployed. Small Business Economics, 42(4): 787-814.

Chen, K \& Hsu, C. (2014). Steadying the ladder China's agricultural and rural development engagement in Africa. China Agricultural Economic Review, 6(1): 2-20.

De Vos, AD, Strydom, H, Fouche', C \& Delport, C. (2010). Research at grassroots. Pretoria: Van Schaick. Department of Basic Education. (2013). Levels of Education in South Africa. Retrieved from http://www.education.co.za/levels-ofeducation-in-south-africa, date: 24 March 2015.

Dubihlela, J., \& Dubihlela, D. (2014). Social Grants Impact on Poverty among the Female-Headed Households in South Africa: A Case Analysis. Mediterranean Journal of Social Sciences, 5(8): 160-179.

Engle, P. L. \& Black, M. M. (2008). The Effect of Poverty on Child Development and Educational Outcomes. Annals of the New York Academy of Sciences, 1136 (1): 243-256.

Guion, L, Diehl, D \& McDonald, D. (2011). Triangulation: Estabilshing the validity of qualitative studies. Retrieved from http://edis.ifas.ufl.edu, date: 14 May 2015.

Hussein, A. (2009). The use of triangulation in social sciences research: Can qualitative and quantitaive methods be combines? Journal of Comparitive Social Work, 1(1): 1-10.

Klasen, S, \& Woolard, I. (2009). Surviving unemployment without state support: Unemployment and household formation in South Africa. Journal of African economies, 18(1): 1-51.

Lacour, M, \& Tissington, L, D. (2011). The Effects of Poverty on Academic Achievement. Educational Research and Reviews, 6 (7): $522-527$

Lazenby, H. (2014). Junior resource investment could result in handsome profits as markets turn. Mining Weekly, 20 January. Retrieved from http://www.miningweekly.com/, date: 11 August 2015.

Lehohla, P. (2012). Census 2011 municipal report, North West. Pretoria: Statistics South Africa Lemmen, M. (2013). An exploratory study of the experiences of young people in becoming agents of social change in Cape Town. Department of Social Science, University of Cape Town.

Lustig, N., Pessino, C. \& Scott, J. (2014). The impact of taxes and social spending on inequality and poverty in Argentina, Bolivia, Brazil, Mexico, Peru, and Uruguay introduction to the special issue. Public Finance Review, 42(3): 287-303.

Maree, J.G. (2014). Critical appraisal of the system of education and prospects of meeting the manpower and developmental needs of South Africa. Africa Insight, 58(2): 20-39

Martinez, C.D.H. (2013). Measuring social return on investment for community schools. Washington: The Childrens Aid Society

McAllister, P., Street, E., \& Wyatt, P. (2015). Governing calculative practices: An investigation of development viability modelling in the English planning system. Urban Studies, 42 (9): 155-189.

McNiff, J. (2013). Action research principles and practice. 3rd edition. New York: Routledge.

Nafukho, F. (2013). Capacity building through investment in people: Key to Africa's development. European Journal of Training and Development, 37(7): 604 -14.

Saunders, P. (2006). Urban politics: A sociological interpretation (Vol. 9). New York: Routledge.

Sayed, S. \& Badat, Y. (2014). Post-1994 South African education: The challenge of social justice. The ANNALS of the American Academy of Political and Social Science, 652(1): 127-48.

Sekhampu, T.J. (2013). Determinants of poverty in a South African township. Journal of Social Sciences, 34(2): 145-53.

Schepers, D. (2014). Social inequalities as the causes of juvenile delinquency: Heterogeneities in the context of situational action theory. SFB 882 Working Paper Series (Vol 40). Bielefeld: DFG Research Center. Ghent and Bielefeld University Library

Sweeney, S. A., Bazemore, A., Phillips, R. L., Etz, R. S., \& Stange, K. C. (2012). A re-emerging political space for linking person and community through primary health care. American Journal of Preventive Medicine, 42(6): 184-S190. 
Todres, M., Cornelius, D.N., Janjuha-Jivraj, D.S. \& Woods, P.A. (2006). Developing emerging social enterprise through capacity building. Social Enterprise Journal, 2(1): 61-72.

Wataya, E. (20110. Capacity development and training: Blended learning program. Community Environment and Disaster Risk Management, 1:183-201. 


\section{NOTES}

